\title{
Tuberculosis risk in patients with rheumatologic disease treated with biologic drugs
}

\author{
Emine ARGÜDER ${ }^{1}$ (ID) \\ Güniz YANIK \\ ÜSTÜNER ${ }^{2}(I D)$ \\ Remzi EKICi²(ID) \\ Hatice $\mathrm{KILIÇ}^{\mathbf{1}}$ (ID) \\ Şükran ERTEN ${ }^{3}$ (ID) \\ Ayşegül KARALEZLi ${ }^{1}$ (ID)
}

Cite this article as: Argüder E, Yanık Üstüner G, Ekici R, Kılıç $H$, Erten Ş, Karalezli A. Tuberculosis risk in patients with rheumatologic disease treated with biologic drugs. Tuberk Toraks 2020;68(3):236-244.

\section{Yazışma Adresi (Address for Correspondence)}

Dr. Emine ARGÜDER

Yıldırım Beyazıt Üniversitesi Tıp Fakültesi, Göğüs Hastalıkları Anabilim Dalı, ANKARA - TÜRKIYE

e-mail: drgullu2000@gmail.com

OCopyright 2020 by Tuberculosis and Thorax.

Available on-line at www.tuberktoraks.org.com
${ }^{1}$ Department of Chest Diseases, Faculty of Medicine Yildirim Beyazit University, Ankara, Turkey

${ }^{1}$ Ankara Yıldırım Beyazıt Üniversitesi Tıp Fakültesi, Göğüs Hastalıkları Anabilim Dalı, Ankara, Türkiye

${ }^{2}$ Clinic of Internal Medicine, Ankara City Hospital, Ankara, Turkey

${ }^{2}$ Ankara Şehir Hastanesi, iç Hastalıkları Kliniği, Ankara, Türkiye

${ }^{3}$ Department of Rheumatology, Faculty of Medicine Ankara Yildirim Beyazit University, Ankara, Turkey

${ }^{3}$ Ankara Yıldırım Beyazıt Üniversitesi Tıp Fakültesi, Romatoloji Anabilim Dalı, Ankara, Türkiye

\section{ABSTRACT}

Tuberculosis risk in patients with rheumatologic disease treated with biologic drugs

Introduction: The risk of tuberculosis is higher in cases who have used antiTNF treatments. However, it is not clearly known whether there is a relationship between other biologic agents and the risk of developing tuberculosis or not. We aimed to investigate the prevalence of active tuberculosis among patients with rheumatic disease treated with biologic drugs.

Materials and Methods: The study was performed at a tertiary referral center from January 2015 to December 2019. A total of 2000 patients with rheumatic diseases were screened and 461 patients were enrolled in the study due to regular records. They were underwent LTBI screening tests and were followedup at least 1 year after TNF inhibitor treatment initiation.

Results: The median age of all patients was 48 (min-max: 19-80). 283 patients $(61.3 \%)$ were female and $178(38.7 \%)$ were male. The most common diseases were ankylosing spondylitis (67.2\%), rheumatoid arthritis (26\%) and psoriatic arthritis (5.2\%). Anti-TNF treatments were given to $85.2 \%$ of all cases and other biologic treatments were given to $14.8 \%$. Tuberculin skin test was applied to 429 patients and $70.4 \%$ positivity was found. Quantiferon-TB test was applied to 93 patients and $20.4 \%$ positivity was found. 320 patients were treated for LTBI due to positive tuberculin skin test and/or positive quantiferon-TB test. TB was developed in only one patient out of 393 patients who were treated with anti-TNF treatments and the the prevalence of TB development was found 255/100.000.

Conclusion: The incidence of tuberculosis was quite low in our patients with rheumatic disease who were receiving anti-TNF treatment compared to previous studies. Also, in patients who were using other biological treatments, no TB cases were developed.

Key words: Tuberculosis; latent tuberculosis; anti-TNF treatment; biologic treatment; rheumatic disease 


\section{Öz}

\section{Romatolojik hastalık nedeniyle biyolojik ilaçla tedavi edilen hastalarda tüberküloz riski}

Giriş: Anti-TNF tedavisi kullanılan olgularda tüberküloz riski yüksektir. Bununla birlikte, diğer biyolojik ajanlar ile tüberküloz gelişme

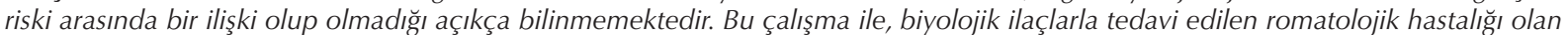
hastalarda aktif tüberküloz insidansını araştırmayı amaçladık.

Materyal ve Metod: Çalışma Ocak 2015-Aralık 2019 arasında üçüncü basamak bir eğitim araştırma hastanesinde gerçekleştirildi. Toplam 2000 romatolojik hastalığı olan hasta tarandı ve 461 hasta düzenli kayıtları olması nedeniyle çalışmaya alındı. Hastalara latent tüberküloz infeksiyonu yönünden tarama testleri yapılmıştı ve TNF inhibitörü tedavisine başlandıktan sonra en az 1 yıl takip edilmişti.

Bulgular: Tüm hastaların ortanca yaşı 48 idi (min-maks: 19-80). Hastaların 283'ü (\%61.3) kadın, 178'i (\%38.7) erkekti. En sık görülen hastalıklar ankilozan spondilit (\%67.2), romatoid artrit (\%26) ve psoriatik artrit (\%5.2) idi. Tüm olguların \%85.2'sine anti-TNF tedavi ve \% 14.8'ine diğer biyolojik tedaviler verilmişti. 429 hastaya tüberkülin deri testi uygulanmış ve \% 70.4'ü pozitif bulunmuştur. 93 hastaya Quantiferon-TB testi uygulanmış ve \%20.4'ü pozitif bulunmuştur. 320 hastanın pozitif tüberkülin deri testi ve/veya pozitif quantiferon-TB testi nedeniyle tüberküloz profilaksisi uygulandı. Anti-TNF tedavi alan 393 hastadan sadece birinde TB gelişti ve TB gelişme prevalansı 255/100.000 olarak bulundu.

Sonuç: Anti-TNF tedavisi gören romatolojik hastalığı olan hastalarımızda tüberküloz insidansı daha önceki çalısmalara göre oldukça düşüktü. Diğer biyolojik tedavileri kullanan hastalarda ise TB olgusu bildirilmedi.

Anahtar kelimeler: Latent tüberküloz; anti-TNF tedavisi; biyolojik tedavi; romatolojik hastalık; tüberküloz

\section{INTRODUCTION}

Tuberculosis (TB) remains a major public health problem on a worldwide scale. Although important progress has been made toward eradication of TB, it is still a leading cause of morbidity and mortality. Eradication of TB is based upon early case-finding, efficient infection control precautions, and prevention of latent TB infection (LTBI) reactivation. Almost 1.7 billion subjects have been estimated as infected with Mycobacterium tuberculosis (Mtb) around the world. More than 10 million people get TB every year (1). Advanced diagnostic tests such as rapid molecular testing and whole-genome sequencing have provided significant contribution for the diagnosis. The main affected area is lungs in the most cases, but extra-pulmonary systems may also be affected. In the treatment of TB, Directly Observed Therapy (DOT) helps patients to take their medication regularly and complete the treatment. Thus, patients can reach to fruition by the treatment and drug resistance is prevented (2-4).

Latent TB infection (LTBI) is a condition in which a person is infected with Mtb, but does not have active TB disease. These people have no signs and symptoms of the diseases (5). However, the persons who are infected with Mtb have a $5-10 \%$ probability of active infectious TB disease throughout their lives. The activation often occurs within the first five years after infection. Activation risk may vary depending on various factors, especially immunological status (6).
Since LTBI shows subclinical course, it is not possible to recognize it clinically. The diagnosis of LTBI is made by Tuberculin Skin Test (TST) and Interferon Gamma Release Assay (IGRA). IGRA is a blood assay and includes QuantiFERON Plus (QFT-P; Qiagen, Hilden, Germany) and T-SPOT.TB (Oxford Immunotec, Abingdon, UK). These tests measure cell-mediated immunity against TB. They become positive six to eight weeks after infection. They can be used individually or together. Accuracy rates of both tests in LTBI detection are similar $(7,8)$. There may be a problem in the diagnosis of LTBI due to false positive and false negative results in TST. This should be taken into account in the diagnosis of LTBI. The decision should be made by patient-based evaluation and not only by technical measurement of the test. Accordingly, a second test (boosting effect) or validation with IGST may be required (9).

Nowadays, the use of various biological agents is gradually increasing for rheumatic diseases. However, the risk of TB is higher in cases who have used antiTNF treatments (10). However, it is not clearly known whether there is a relationship between every biologic agents and the risk of developing TB. Most biological drugs increase the risk of TB reactivation by disrupting the granuloma structure due to their action on effectors of the immune response. It was shown that the changes in TNF alpha levels as affected by antiTNF treatments have been associated with the increased sensitivity to reactivate TB in LTBI subjects. In addition, rheumatic patients also have an increased 
risk of TB due to the underlying autoimmune disease (11).

In our country, the incidence of TB is 16/100.000 (4). The variety and use of biological drugs in rheumatic diseases are increasing day by day. Thus, we aimed to investigate the prevalence of active TB among patients with rheumatic disease treated with biologic drugs.

\section{MATERIALS and METHODS}

The study was performed at a tertiary referral center from January 2015 to December 2019. The study protocol was approved by the local Ethics committee. A total of 2000 patients with rheumatic diseases were screened and 461 patients were enrolled in the study due to regular records. Demographic data (age, gender) of the patients were recorded from the patient records. Then, diagnosis of the rheumatic disease, duration of the disease, previous treatments and/or planned treatments (anti-TNF or other biologic agents), TST results, quantiferon-TB tests results, whether isoniazid prophylaxis was applied or not, findings of chest X-ray were recorded.

In our country, all patients are evaluated for LTBI before anti-TNF treatments and other biologic agents due to pharmacovigilance regulations. At our institution, TST and/or an IGRA, chest X-ray were performed for all patients for screening LTBI. TST was performed by using Mantoux method and was evaluated 72 hours later. The test was regarded as positive if induration dimension was higher than $\geq 5 \mathrm{~mm}$ according to 2011 Tuberculosis Diagnosis and Treatment National Guideline (12). If the first reaction diameter was between 0 and $4 \mathrm{~mm}$, the test was repeated 1 or 2 weeks later to evaluate the booster phenomenon. If active TB is suspected in any patient at our center, the patient is evaluated in detail. For this, chest X-ray, sputum acidoresistant bacilli (ARB) staining, sputum Mtb polymerase chain reaction (PCR) examination and Mtb culture in sputum are performed, and thorax computerized tomography (CT) and/or bronchoscopy are performed if necessary.

For patients with $\mathrm{LTBI}$, whose active TB was ruled out, if the following occurred; TST $\geq 5 \mathrm{~mm}$, positive quantiferon-TB test, fibrotic changes in the chest $X$-ray or having close contact with a patient with active TB in the past 1 year and isoniazid treatment is planned (300 mg/day) for 9 months. One month later anti-TNF agents or other agents are started. Patients who have started anti-TNF or other treatments are followed up with regular 3 months controls and the patient is evaluated for TB reactivation at each control.

\section{Statistical analysis}

Distribution of age was examined by Shapiro-Wilk test. Since age didn't distribute normally, patients' ages were taken by median (min-max). Categorical variables were expressed as numbers or percentages. Chi square test was used to compare the grouped data. $p<0.05$ value was considered statistically significant. All analyses were performed via IBM SPSS Statistics 21.0 (IBM Corp. Released 2012. IBM SPSS Statistics for Windows, Version 21.0, Armonk, NY: IBM Corp.).

\section{RESULTS}

A total of 461 patients were enrolled in the study. The median age of all patients was 48 (min-max: 19-80) and the mean of ages was $47.45 \pm 11.85 .283$ patients $(61.3 \%)$ were female and $178(38.7 \%)$ were male. When the cases were compared according to gender, a statistically significant difference was found between the mean ages $(p<0.001)$. The mean of disease duration of the cases was $12.59 \pm 7.17$ years. The duration of disease was longer in men $(p=$ 0.021). Some of the patients had one disease; some had more than one disease. The most common diseases were ankylosing spondylitis $(67.2 \%)$, rheumatoid arthritis (26\%) and psoriatic arthritis (5.2\%). When the cases were compared according to gender; ankylosing spondylitis was high in men, rheumatoid arthritis was high in women and there was statistically significant difference (respectively; $p<0.001$ and $\mathrm{p}<0.001$ ). Anti-TNF treatments were given to $85.2 \%$ of all cases and other biologic treatments were given to $14.8 \%$ (Table 1 ).

All of the patients with rheumatic diseases were screened for LTBI with TST $(n=429,93.1 \%)$ and/or quantiferon-TB test $(n=93,20.2 \%) .70 .4 \%(n=302)$ positivity was found in the results of patients who underwent TST and $20.4 \%(n=19)$ positivity was found in the results of patients who underwent quantiferon-TB test (Table 2). We did not reach Booster test results. Both TST and quantiferon-TB tests were performed in only 65 patients. Both tests were negative in 47 cases, in 4 cases TST was negative and quantiferon-TB test was positive, in 8 cases TST was positive and quantiferon-TB test was negative, and 
Table 1. The features of rheumatic patients according to gender

\begin{tabular}{|c|c|c|c|c|}
\hline & Total $(n=461)$ & Female $(n=283)$ & Male $(n=178)$ & $\mathbf{P}$ \\
\hline Age $($ mean $\pm \mathrm{SD})$ & $47.45 \pm 11.85$ & $49.73 \pm 11.72$ & $43.83 \pm 11.16$ & $<0.001$ \\
\hline Disease duration (years) (mean $\pm \mathrm{SD}$ ) & $12.59 \pm 7.17$ & $11.32 \pm 6.75$ & $13.98 \pm 7.39$ & 0.021 \\
\hline \multicolumn{5}{|l|}{ The frequencies of rheumatic disease $\mathrm{n}(\%)$} \\
\hline Ankylosing spondylitis & $310(67.2)$ & $156(55.1)$ & $154(86.5)$ & $<0.001$ \\
\hline Rheumatoid arthritis & $120(26.0)$ & $105(37.1)$ & $15(8.4)$ & $<0.001$ \\
\hline Psoriatic arthritis & $24(5.2)$ & $16(5.7)$ & $8(4.5)$ & 0.582 \\
\hline Familial Mediterranean fever & $11(2.4)$ & $9(3.2)$ & $2(1.1)$ & 0.137 \\
\hline Behcet's disease & $6(1.3)$ & $5(1.8)$ & $1(0.6)$ & 0.238 \\
\hline Sjögren's syndrome & $1(0.2)$ & $1(0.4)$ & $0(0)$ & 0.323 \\
\hline Systemic lupus erythematosus & $1(0.2)$ & $1(0.4)$ & $0(0)$ & 0.323 \\
\hline \multicolumn{5}{|c|}{ Biologic treatments used for rheumatological disease } \\
\hline Anti-TNF treatments & $393(85.2)$ & $225(79.5)$ & $168(94.4)$ & $<0.001$ \\
\hline Other biologic treatments & $68(14.8)$ & $58(20.5)$ & $10(5.6)$ & $<0.001$ \\
\hline
\end{tabular}

Table 2. The results of TST, Quantiferon-TB test, Chest X-ray findings and treatment of LTBI

\begin{tabular}{|c|c|c|}
\hline Total $n=461$ & $\mathbf{n}$ & $\%$ \\
\hline \multicolumn{3}{|l|}{ Tuberculin skin test $(n=429)$} \\
\hline 0-4 mm (negative) & 127 & 29.6 \\
\hline$\geq 5$ (positive) & 302 & 70.4 \\
\hline \multicolumn{3}{|l|}{ Quantiferon-TB test $(n=93)$} \\
\hline Negative & 74 & 79.6 \\
\hline Positive & 19 & 20.4 \\
\hline \multicolumn{3}{|l|}{ Chest $X$-ray findings $(n=461)$} \\
\hline Normal & 456 & 98.9 \\
\hline Fibrotic changes & 5 & 1.1 \\
\hline \multicolumn{3}{|l|}{ Isoniazid prophylaxis } \\
\hline Yes & 319 & 69.2 \\
\hline No & 138 & 29.9 \\
\hline Received rifampicin due to high liver function test & 1 & 0.2 \\
\hline Cessation of treatment due to nausea & 1 & 0.2 \\
\hline TB treatment as an adult & 1 & 0.2 \\
\hline TB treatment as a child & 1 & 0.2 \\
\hline
\end{tabular}

both tests were positive in 6 cases. Overall, the results were considered to be consistent. When patients' chest X-ray results were evaluated, 456 $(98.9 \%)$ of them had normal appearance and fibrotic changes were seen in $5(1.1 \%)$ (Table 2$)$.

320 patients were treated for LTBI due to positive tuberculin skin test and/or positive quantiferon-TB test. $319(69.2 \%)$ of them was treated with isoniazid and only one $(0.2 \%)$ of them was treated with rifampicin due to high liver function test. One $(0.2 \%)$ of them had received TB treatment as a child and $1(0.2)$ of them had received TB treatment as an adult due to active TB disease. Only $1(0.2 \%)$ of them could not be treated for LTBI due to severe nausea (Table 2). In addition, one patient had been treated with isoniazid prophylaxis 8 years ago due to TB contact.

These patients with rheumatic diseases were treated by various biological agents by the Department of Rheumatology. Anti-TNF treatments were given to $85.2 \%$ of all cases; etanercept was given to 156 
Tuberculosis risk in patients with rheumatologic disease treated with biologic drugs

Table 3. Biologic treatments used for rheumatologic disease

\begin{tabular}{|lcc|}
\hline Total $\mathbf{n}=\mathbf{4 6 1}$ & $\mathbf{n}$ & $\mathbf{\%}$ \\
\hline Anti-TNF treatments $(\mathrm{n}=393)$ & & 33.8 \\
$\quad$ Etanercept & 156 & 23.4 \\
Adalimumab & 108 & 10.8 \\
Golimumab & 50 & 10.6 \\
Certolizumab & 49 & 6.5 \\
Infliximab & 30 & 6.1 \\
Other biologic treatments $(\mathrm{n}=68)$ & & 3.5 \\
Tofacitinib & 28 & 1.5 \\
Tocilizumab & 16 & 1.3 \\
Secukinimab & 7 & 1.1 \\
Rituximab & 6 & 0.7 \\
Canakinumab & 5 & 0.7 \\
Abatacept & 3 & \\
Anakinra & 3 & \\
\hline
\end{tabular}

$(33.8 \%)$, adalimumab was given to $108(23.4 \%)$, golimumab was given to $50(10.8 \%)$, certolizumab was given to $49(10.6 \%)$, infliximab was given to 30 $(6.5 \%)$. Other biologic treatments were given to $14.8 \%$; tofacitinib was given to $28(6.1 \%)$, tocilizumab was given to 16 (3.5\%), secukinimab was given to $7(1.5 \%)$, rituximab was given to $6(1.3 \%)$, canakinumab was given to 5 (1.1), abatecept was given to 3 $(0.7 \%)$ and anakinra was given to $3(0.7 \%)$ (Table 3$)$.

TB was developed in only one patient out of 393 patients treated with anti-TNF treatments (prevalence 255/100.000). She had both constitutional and respiratory symptoms and was diagnosed with miliary TB. The patient was being followed up for 3 years due to Behçet's disease. Her husband had pulmonary TB 8 years ago and she had received isoniasid prophylaxis. Since the patient had negative TST ( $4 \mathrm{~mm}$ ) and she had not received re-preventive treatment. Booster test and quantiferon test were not applied. She was treated with infliximab 1 month ago and was diagnosed with milliary TB. The patient was given antituberculous treatment for 6 months. Apart from this case, no other TB case was encountered.

\section{DISCUSSION}

Approximately a quarter of the world's population has LTBI and 5-10\% of them develop active TB as a result of impaired immune systems. Especially, LTBI can be reactivated under various conditions such as malnutrition, immunosuppression or solid organ transplantation (6). Also, autoimmune diseases are associated with the risk of TB. Especially rheumatoid arthritis (RA) patients have an increased risk from 2.0 to 8.9 (13). The reasons for increased risk of TB in patients with RA are male gender, advanced age, the use of corticosteroids and comorbidities (diabetes mellitus, chronic obstructive pulmonary disease, chronic renal disease) (14). In the past 20 years, important steps have been taken in the treatment of axial spondyloarthritis such as RA, PA and AS and other rheumatic diseases. In particular, biological agents that specifically inhibit different stages or cytokines of the immune response provided satisfactory results in the treatment of those diseases (15). Today, biological drugs are divided into two main groups. The first group includes anti-TNF agents such as infliximab (IFX), adalimumab (ADA), golimumab (GOL), certolizumab pegol (CZP) and etanercept (ETN). Of these, IFX, ADA, GOL and CZP are monoclonal antibodies directed against TNF alpha, while etanercept is a recombinant human fusion protein. Second group contains non-anti-TNF biological drugs; anti-Interleukin (IL)-1 anakinra (ANK), IL-6 inhibitor tocilizumab (TCZ), anti-CD20 rituximab (RTX), anti-CD28 abatacept (ABA), anti-IL12- 23 ustekinumab (UTK) and anti-interleukin-17 (IL17) secukinumab (SCK) and ixekizumab (IXE) (16). In our cases, the most common diseases were ankylosing spondylitis, rheumatoid arthritis and psoriatic arthritis. The most commonly used treatments were etanercept, adalimumab, golimumab and certolizumab, but many new biological agents were also used.

Tumor necrosis factor (TNF) and other proinflammatory cytokines play an important role in the develop- 
ment of natural and acquired immunity against TB. TNF, by stimulating macrophages and increasing chemokine release, contributes to killing of mycobacterium in the cell. It limits the spread of bacillus and is important in stabilizing the granuloma (17). But, especially anti-TNF treatments disrupt granuloma structure and increase the risk of TB reactivation. The risk of developing TB has been shown mostly in patients taking anti-TNF treatments and it has been reported that this risk may be 1.6-25 times more for those who were using anti-TNF treatments (18-20). In addition, monoclonal antibodies have been reported to increase TB risk more than receptor fusion proteins (10).

In Turkey, previous studies investigated the frequency of TB development in patients using anti-TNF treatments and TB development risk has been shown to increase 9.5-40 times in the patients with rheumatologic diseases (21-24). In a comprehensive study in our country, the risk of developing TB was evaluated in 1887 rheumatology patients. Cagatay et al showed that ADA treatment $(9.5 \times$ increase), male gender (15.6x increase) and previous TB disease history (11.5 $\times$ increase) were risk factors for active TB (22). Hanta et al evaluated 192 patients with rheumatic diseases treated with anti-TNF treatments. They found the frequency of TB development as $1.6 \%$ of the patients (23). Börekçi et al showed that the incidence of TB was 466/100.000 in those who were using anti-TNF treatments in their study (24). In our study, we showed that TB prevalence 255/100.00 in patients with rheumatic diseases treated with antiTNF treatments. There was no patient in our study who was known to be HIV positive, but the patient who developed TB had a history of TB contact in the previous years.

On the contrary, the inhibition of CD20, CD28, IL-1, IL-6, IL-12, IL-23, and IL-17 have insignificant effects on TB granuloma. Namely, biological drugs such as RTX, ABA, ANK, TCZ, UTK, SCK, and IXE have a negligible or absent effect on TB reactivation (25). For example, IL-6 plays a role in TB granuloma maintenance and TCZ influence IFN- $\gamma$ synthesis minimally by TB antigens. In the literature, there are small numbers of publications showing that TB develops in patients using TCZ. On the other hand, TB reactivation was not encountered in 19 studies evaluating the risk of TB in patients using TCZ. There are similar results for the trials using RTX, ABA, and UTK (16). Also clinical observations for SCK show a low risk of
TB reactivation $(26,27)$. According to $\mathrm{WHO}$ guidelines recommended for non-anti-TNF biologics, LTBI screening in low TB risk countries seems unnecessary, except in high TB risk subjects $(25,28)$. In our country, LTBI screening was recommended for patients who will receive non-anti-TNF biologics. Additionally, there was no TB development in the patients treated with other biologic agents.

A screening for LTBI including preventive therapy is very important for the patients with rheumatic diseases who will receive biological drugs. Two types of tests, namely TST and IGRA are used to investigate LTBI, and both have some advantages and disadvantages. TST remains to be an inexpensive test that does not require equipment on a worldwide scale. Assessment with TST is based on intradermal injection of purified protein derivative which induces a delayed-type hypersensitivity response and the size of induration occurring after 48-72 hours. The specificity of TST is low, because the antigen used in the test is not specific to Mtb (29). IGRA tests measure IFN-gamma production after specific stimulation of whole blood or peripheral blood mononuclear cells using the ELISA or enzyme-linked immunospot (ELISPOT) assay (8). The sensitivity of TST is lower, especially in patients who have used steroids for more than $20 \mathrm{mg}$ for at least 2 weeks, which is likely to be seen in the most of patients beginning anti-TNF treatment (30). In this case, IGRA can be preferred, however, both tests cannot distinguish active and latent TB (8). None are better at identifying patients with rheumatic diseases that may benefit from preventive chemoprophylaxis. In the literature, it has not been clearly defined which test is more cost-effective for the economic evaluation of LTBI screening. Lowincome countries should continue to use TST as the primary method for the diagnosis of LTBI. WHO reported that both TST and IGRA were acceptable in LTBI screening $(6,31)$. TST is still being used as the first choice for LTBI scanning at our center.

During screening of LTBI, if either test (TST or IGRA) is positive, active TB should firstly be excluded both clinically and radiologically. In case of TB suspicion, Mtb must be investigated microbiologically. Otherwise, preventive treatment should start when active TB is not detected. If both tests are negative after screening and the patient has no clinical and radiological suspicion in terms of TB, LTBI is excluded and preventive treatment is not required. Additionally, during these evaluations, it should be taken into con- 
sideration that IGRA and TST may show false positivity and false negativity (16). TST was applied to most of our cases and according to those results, a preventive treatment plan was decided for the patients as a result of clinical and radiological evaluation. In many guidelines, annual screening for LTBI is recommended for patients receiving biological therapy (16). However, in regions with low TB incidence, repeated LTBI screening can sometimes lead to disruption of biological treatment and unnecessary antibiotic toxicity due to false test positivity (32).

Treating LTBI is indicated for its possibility of turning into active TB. In LTBI, some focuses contain live bacilli. The treatment is performed by destroying replicated bacilli. Isoniazid inhibits cell wall synthesis, cell wall synthesis occurs under replication. Isoniazid prophylaxis could effectively reduce TB risk in biologics-exposed patients and by LTBI treatment, the progression of LTBI to active TB disease could be prevented by $60-90 \%$. Instead of treating the TB patient after development of active disease; treating $\mathrm{LTBI}$ cases at high risk of reactivation is a more acceptable approach in many ways $(33,34)$. The guidelines recommend 9 months of isoniazid prophylaxis for the treatment of LTBI. However, this long-term treatment can sometimes cause hepatotoxicity; in this case, alternative treatments may be an option (13). At our center, LTBI treatment for 9 months was assigned by positive TST, positive IGRA or squealed changes on chest $\mathrm{X}$-ray suggestive of resolved TB infection. Also, it was shown that preventive therapy against TB reactivation has been shown to be well tolerated by rheumatic patients requiring biological medication after proper LTBI scanning.

More than half of TB developing in patients using antiTNF is extrapulmonary TB. Lung TB and disseminated TB follow that $(9,22)$. In our study, only one patient was diagnosed with miliary TB. LTBI treatment has been shown to lead to a $25-92 \%$ (average $60 \%$ ) reduction in disease occurrence. Protection in the presence of $80 \%$ compliance with recommended doses; while it was $69 \%$ with the 6-month $\mathrm{INH}$ regimen, it was reported as $93-97 \%$ with the 12 -month $\mathrm{INH}$ regimen. It has also been shown that the protection obtained continues for 19 years. LTBI treatment can be re-administered in some risky patients and in cases that have passed after previous LTBI treatment (35). Since the she had received isoniasid prophylaxis and she had negative TST, she had not received re-preventive treatment. Additionally, we know in recent studies that
TB risk with the monoclonal anti-TNF antibodies is higher than with the fusion protein etanercept (10). Therefore, less risky treatments may be preferred in patients with high risk of developing TB.

There were several limiting conditions due to the retrospective nature of our study, it is expected that there will be deficiencies in the recording of clinical and laboratory findings. Also, in cases where IGRA could not be performed and TST was negative, the Booster test was found to be insufficient. As a result, when compared to the results of previous studies, the prevalence of TB was quite low in our patients receiving anti-TNF treatment. In patients using other biological treatments, no TB cases had been developed. It was thought that regular follow-up of our cases, screening of each case for LTBI prior to both anti-TNF and other biologic treatments and prophylaxis treatment to the required cases prevented the development of TB as a result of increasing experience. We would like to emphasize once again the importance of patient's history, chest X-ray, TST and/or quantiferon-TB test in LTBI screening.

\section{CONFLICT Of INTEREST}

There is no conflict of interest related to this study.

Ethics Committee Approval: The approval for this study was obtained from Ankara City Hospital Clinical Research Ethics Committee (Decision No: E1/821/2020 Date: 25.06.2020).

\section{AUTHORSHIP CONTRIBUTIONS}

Concept/Design: EA, HK

Analysis/Interpretation: EA, HK

Data Acquisition: GÜY, RE

Writting: EA

Critical Revision: AK, ŞE

Final Approval: HK, AK, ŞE

\section{REFERENCES}

1. Houben RM, Dodd PJ. The global burden of latent tuberculosis infection: a re-estimation using mathematical modelling. PLoS Med 2016; 13: e1002152.

2. Furin J, Cox H, Pai M. Tuberculosis. Lancet 2019; 393: 1642-56.

3. Browne SH, Umlauf A, Tucker AJ, Low I, Moser K, Gonzalez Garcia J, et al. Wirelessly observed therapy compared to directly observed therapy to confirm and support tuberculosis treatment adherence: a randomized controlled trial. PLoS Med 2019; 16: e1002891. 
4. World Health Organization (WHO). Global Tuberculosis Report 2017. Geneva: World Health Organization; 2017. Available from: https://www.who.int/tb/publications/ global_report/gtbr2017 main_text.pdf.

5. Tuberculosis. Nat Rev Dis Primers 2016; 2: 16077.

6. Latent tuberculosis infection. Updated and consolidated guidelines for programmatic management. Erişim Tarihi: 16 Mayıs 2020. Available from: https://apps.who.int/iris/ bitstream/handle/10665/260233/9789241550239-eng. pdf; jsessionid=0725D5FAD3504015DF681076F486C02 0 ? sequence $=1$

7. Domínguez J, Latorre I, Santin M. Diagnosis and therapeutic approach of latent tuberculosis infection. Enferm Infect Microbiol Clin 2018; 36: 302-11.

8. Goletti D, Sanduzzi A, Delogu G. Performance of the tuberculin skin test and interferon-g release assays: an update on the accuracy, cutoff stratification, and new potential immune-based approaches. I Rheumatol (Suppl) 2014; 91: 24-31.

9. Paton NI, Borand L, Benedicto J, Kyi MM, Mahmud AM, Norazmi MN, et al. Diagnosis and management of latent tuberculosis infection in Asia: review of current status and challenges. Int J Infect Dis 2019; 87: 21-9.

10. Kelsey A, Chirch LM, Payette MJ. Tuberculosis and interleukin blocking monoclonal antibodies: Is there risk? Dermatol Online J 2018; 24(9): 13030.

11. Baddley JW, Cantini F, Goletti D, Gómez-Reino JI, Mylonakis E, San-Juan R, et al. ESCMID Study Group for Infections in Compromised Hosts (ESGICH) Consensus Document on the safety of targeted and biological therapies: an infectious diseases perspective (Soluble immune effector molecules [I]: anti-tumor necrosis factor-a agents). Clin Microbiol Infect 2018; 24 (Suppl 2): S10-S20.

12. T. C. Ministry of Health. The Guidelines of Tuberculosis Diagnosis and Treatment, 2011. Available from: https:// www.toraks.org.tr/uploadFiles/30102014133530tuberkul oz_tani_ve_tedavi_rehberi.pdf

13. Cantini F, Nannini C, Niccoli L, lannone F, Delogu G, Garlaschi G, et al. SAFEBIO (Italian multidisciplinary task force for screening of tuberculosis before and during biologic therapy). Guidance for the management of patients with latent tuberculosis infection requiring biologic therapy in rheumatology and dermatology clinical practice. Autoimmun Rev 2015; 14: 503-9.

14. Chiu YM, Chen DY. Infection risk in patients undergoing treatment for inflammatory arthritis: non-biologics versus biologics. Expert Rev Clin Immunol 2020; 16: 207-28.

15. Nam IL, Takase-Minegishi K, Ramiro S, Chatzidionysiou K, Smolen IS, van der Heijde D, et al. Efficacy of biological disease-modifying antirheumatic drugs: a systematic literature review informing the 2016 update of the EULAR recommendations for the management of rheumatoid arthritis. Ann Rheum Dis 2017; 76: 1113-36.
16. Goletti D, Petrone L, Ippolito G, Niccoli L, Nannini C, Cantini F. Preventive therapy for tuberculosis in rheumatological patients undergoing therapy with biological drugs. Expert Rev Anti Infect Ther 2018; 16: 501-12.

17. Dobler CC. Biologic Agents and Tuberculosis. Microbiol Spectr 2016; 4.

18. Dixon WG, Watson $K$, Lunt $M$, Hyrich $K L$, Silman $A J$, Symmons DP, et al. Rates of serious infection, including site-specific and bacterial intracellular infection, in rheumatoid arthritis patients receiving anti-tumor necrosis factor therapy: results from the British Society for Rheumatology Biologics Register. Arthritis Rheum 2006; 54: 2368-76.

19. Wallis RS, Broder $M$, Wong J, Beenhouwer D. Granulomatous infections due to tumor necrosis factor blockade: correction. Clin Infect Dis 2004; 39: 1254-5.

20. Wolfe F, Michaud K, Anderson J, Urbansky K. Tuberculosis infection in patients with rheumatoid arthritis and the effect of infliximab therapy. Arthritis Rheum 2004; 50: 372-9.

21. Elbek O, Uyar M, Aydin N, Börekçi S, Bayram N, Bayram $H$, et al. Increased risk of tuberculosis in patients treated with antitumor necrosis factor alpha. Clin Rheumatol 2009; 28: 421-6.

22. Cagatay T, Bingol Z, Kıyan E, Yegin Z, Okumus G, Arseven $O$, et al. Follow-up of 1887 patients receiving tumor necrosis-alpha antagonists: Tuberculin skin test conversion and tuberculosis risk. Clin Respir J 2018; 12: 1668-75.

23. Hanta I, Ozbek S, Kuleci S, Kocabas A. The evaluation of latent tuberculosis in rheumatologic diseases for anti-TNF therapy: experience with 192 patients. Clin Rheumatol 2008; 27: 1083-6.

24. Borekci S, Atahan E, Demir Yilmaz D, Mazıcan N, Duman $B$, Ozguler Y, et al. Factors affecting the tuberculosis risk in patients receiving anti-tumor necrosis factor-a treatment. Respiration 2015; 90: 191-8.

25. Cantini F, Nannini C, Niccoli L, Petrone L, Ippolito G, Goletti D. Risk of tuberculosis reactivation in patients with rheumatoid arthritis, ankylosing spondylitis, and psoriatic arthritis receiving non-anti-TNF-targeted biologics. Mediators Inflamm 2017; 2017: 8909834.

26. Kherani I, Chin C, Kherani RB, Kherani F. Refractory giant cell arteritis on prednisone and tocilizumab: improvement with subsequent tuberculosis reactivation. Can I Ophthalmol 2019; 54: e192-e194.

27. Ogata A, Mori M, Hashimoto S, Yano Y, Fujikawa T, Kawai $M$, et al. Minimal influence of tocilizumab on IFN-gamma synthesis by tuberculosis antigens. Mod Rheumatol 2010; 20: 130-3.

28. Cantini F, Niccoli L, Capone A, Petrone L, Goletti D. Risk of tuberculosis reactivation associated with traditional disease modifying anti-rheumatic drugs and non-antitumor necrosis factor biologics in patients with rheumatic disorders and suggestion for clinical practice. Expert Opin Drug Saf 2019; 18: 415-25. 
29. Pahal P, Sharma S. PPD Skin Test (Tuberculosis Skin Test). 2020. StatPearls [Internet]. Treasure Island (FL): StatPearls Publishing; 2020. Available from: http://www.ncbi.nlm. nih.gov/books/NBK556037/

30. Carmona L, Gómez-Reino Jl, Rodríguez-Valverde V, Montero D, Pascual-Gómez E, Mola EM, et al. Effectiveness of recommendations to prevent reactivation of latent tuberculosis infection in patients treated with tumor necrosis factor antagonists. Arthritis Rheum 2005; 52: 1766-72.

31. Getahun H, Matteelli A, Chaisson RE, Raviglione M. Latent Mycobacterium tuberculosis infection. N Engl / Med 2015; 372: 2127-35.

32. Johnson MG, Bialas RW, Hall RP, Stout JE. Should all patients undergoing treatment with biologic agents be screened annually for latent tuberculosis infection with an interferon gamma release assay? I Dermatolog Treat 2016; 27: $378-80$.
33. Carvalho I, Goletti D, Manga S, Silva DR, Manissero D, Migliori G. Managing latent tuberculosis infection and tuberculosis in children. Pulmonology 2018; 24: 106-14.

34. Getahun H, Matteelli A, Chaisson RE, Raviglione M. Latent Mycobacterium tuberculosis infection. N Engl I Med 2015; 372: 2127-35

35. Özlü T. Latent tüberküloz enfeksiyonu ve tedavisi. Akciğer Sağ/ı̆̆ ve Yoğun Bakım Derneği. 2018. Available from: http://www.asyod.org/dokuman/4092018105427.pdf. 